\title{
Macular hole: 10 and 20-MHz ultrasound and spectral-domain optical coherence tomography
}

\author{
Buraco macular: ultrassonografia de 10 e 20 MHz e tomografia óptica de domínio espectral \\ Juliana Mantovani Bottós ${ }^{1}$, Virginia Laura Lucas Torres², Liliane Andrade Almeida KaneCadan ${ }^{1}$, Andrea Alejandra Gonzalez Martinez ${ }^{1}$, \\ Nilva Simeren Bueno Moraes ${ }^{1}$, Mauricio Maia ${ }^{1}$, Norma Allemann ${ }^{1}$
}

\begin{abstract}
Purpose: Optical coherence tomography $(\mathrm{OCT})$ is valuable for macula evaluation However, as this technique relies on light energy it cannot be performed in the presence of opaque media. In such cases, the ultrasound (US) may predict some macular features. The aim of this study was to characterize images obtained by ultrasound with 10 and 20-MHztransducers comparing to OCT, as well as to analyze the relationship between the vitreous and retina in eyes with macular hole $(\mathrm{MH})$.

Methods: 29 eyes of 22 patients with biomicroscopic evidence of $\mathrm{MH}$ at different stages were included. All patients were evaluated using ultrasonography with 10 and 20-MHz transducers and OCT.

Results: OCT identified signs of $\mathrm{MH}$ in 25 of 29 eyes. The remaining 4 cases no identified by US were pseudoholes caused by epiretinal membranes. In MH stages I ( 2 eyes) and II (1 eye), both transducers were not useful to analyze the macular thickening, but suggestive findings as macular irregularity, operculum or partial posterior vitreous detachment (PVD) were highlighted. In stages III (14 eyes) and IV (5 eyes), both transducers identified the double hump irregularity and thickening. US could measure the macular thickness and other suggestive findings for $\mathrm{MH}$ : operculum, vitreomacular traction and partial or complete PVD. In cases of pseudoholes, US identified irregularities macular contour and a discrete depression. Conclusion: 10-MHz US was useful for an overall assessment of the vitreous body as well as its relationship to the retina. The $20-\mathrm{MHz}$ transducer allowed valuable information on the vitreomacular interface and macular contour. OCT provides superior quality for fine morphological study of macular area, except in cases of opaque media. In these cases, and even if OCT is not available, the combined US study is able to provide a valid evaluation of the macular area improving therapeutic approach
\end{abstract}

Keywords: Retinal perforations/ultrasonography; Tomography, optical coherence/ instrumentation; Transducers; Vitreous detachment/diagnosis

\begin{abstract}
RESUMO
Objetivo: A tomografia de coerência óptica (OCT) é um método diagnóstico valioso para estudo da mácula. Entretanto, por se basear na energia luminosa, não pode ser realizada quando existe opacidade de meios. Nesses casos, o ultrassom (US) pode predizer algumas características maculares. Este estudo teve como objetivos caracterizar imagens obtidas por US com transdutores de 10 e 20-MHz comparadas ao OCT, assim como analisar a relação vitreorretiniana em olhos com buraco macular (BM). Métodos: Vinte e nove olhos de 22 pacientes com evidência biomicroscópica de $B M$ em diferentes estágios foram incluídos. Todos os pacientes foram avaliados com ultrassonografia utilizando transdutores de 10 e 20-MHz e OCT de domínio espectral. Resultados: OCT diagnosticou BM em 25 dentre 29 olhos estudados. Os 4 casos não identificados por US eram pseudoburacos decorrentes de membrana epirretiniana. Nos BM estágios I (2 olhos) ell (1 olho), ambos transdutores não foram úteis para analisar o espessamento macular, mas foram identificados sinais sugestivos como irregularidade macular, opérculo ou descolamento parcial do vítreo posterior (DVP). Nos estágios III (14 olhos) eIV (5 olhos), ambos transdutores identificaram irregularidade, dupla corcova e espessamento macular. O US foi capaz de medir a espessura macular e identificar outros indícios de BM, como opérculo, tração vitreorretiniana e DVP. Em pseudoburacos, o US identificou irregularidades no contorno macular e discreta depressão.

Conclusão: US de 10-MHz foi útil para uma avaliação global do corpo vítreo e sua relação à retina. O US de 20-MHz forneceu informações importantes sobre a junção vitreorretiniana e contorno macular. OCT fornece qualidade superior para estudo morfológico da região macular, exceto em casos de opacidade de meios. Nesses casos, ou quando o exame tomográfico não for disponível, o estudo ultrassonográfico de 10 e 20-MHz é capaz de proporcionar análise válida da região macular e auxiliar na abordagem terapêutica.
\end{abstract}

Descritores: Perfurações retinianas/ultrassonografia; Tomografia de coerência óptical instrumentação; Transdutores; Descolamento do vítreo/diagnóstico

\section{INTRODUCTION}

Almost since its inception as a diagnostic imaging technique for ophthalmology, B-mode ultrasound (US) has used center frequencies at or near 10-MHz, which provides good imaging of the eye, including examination in trauma, image of the vitreous, posterior coats, tumors and the orbit. However, because of the greater focal length needed to view the posterior pole, this frequency was not totally useful for macular imaging. Advances in B-mode ophthalmic US have resulted in the development of $20-\mathrm{MHz}$ transducers, providing higher resolution images of the posterior segment ${ }^{(1)}$.
The advent of spectral domain optical coherence tomography (SD-OCT) has provided new insight into the vitreoretinal interface and readily identifies the presence of macular holes $(\mathrm{MH})$ and other vitreomacular diseases ${ }^{(2,3)}$. OCT can be viewed as an optical analog of ultrasound. However, as this technique relies on light energy it can be used only when media (cornea, lens, vitreous) are optically clear. It is also limited to the central fundus (i.e., images are acquired through the pupil), and provides limited depth of penetration (about $1 \mathrm{~mm})^{(1)}$. In cases of media opacity (dense cataract, leukoma, vitreous hemorrhage), the US exam may predict some
Submitted for publication: August 30,2012

Accepted for publication: November 4, 2012

Study carried out at Department of Ophthalmology, Universidade Federal de São Paulo, UNIFESP São Paulo (SP), Brazil.

Physician, Department of Ophthalmology, Universidade Federal de São Paulo - UNIFESP - São Paulo (SP), Brazil.

Physician, Departament of Ophthalmology, Universidade Federal da Paraíba - UFPB - João Pessoa (PB), Brazil.
Funding: No specific financial support was available for this study.

Disclosure of potential conflicts of interest: J.M.Bottós, None; V.L.L.Torres, None; L.A.A.Kanecadan, None; A.A.G.Martinez, None; N.S.B.Moraes, None; M.Maia, None; N.Allemann, None. Correspondence address: Norma Allemann. Avenida Indianópolis, 1.797 - São Paulo (SP) - 04063003 - Brazil - E-mail: norma.allemann@pobox.com 
macular features and provide further assistance for surgery as well as prognosis ${ }^{(1)}$.

Knowledge and understanding of the structure, function and the relationship of the vitreous to some specific ocular diseases is more limited than that of any other ocular structure. This limitation is largely due to clinical difficulties in visualizing the vitreous and the lack of effective methods to study $\mathrm{it}^{(4)}$. High-resolution B-scan US is commonly available to ophthalmologists around the world. If used with the proper technique, this technology may improve understanding of the relationship between the posterior hyaloid membrane (PHM) and the retina in idiopathic $\mathrm{MH}$ mainly when associated with images provided by $\mathrm{OCT}^{(4)}$. Furthermore, the real etiology and the tractional forces related to the pathophysiology of the $\mathrm{MH}$ are not totally clear.

The aim of this study was to evaluate and characterize the data provided by 10 and 20-MHz US and the spectral-domain OCT in MH exploration, as well as to analyze the relationship between the vitreous cortex and the retina in eyes with $\mathrm{MH}$.

\section{METHODS}

This study was carried out under a protocol approved by the Ethics Committee of Federal University of São Paulo, Brazil under number 0709.

Twenty-nine eyes of 22 patients with biomicroscopy evidence of $\mathrm{MH}$ at different stages were included in the study from May to October 2009 (6 months). Patients were evaluated with slit lamp and 75 D fundus contact lens to a clinical diagnosis of evolving or full-thickness idiopathic MH. Gass classification of MH was used ${ }^{(5,6)}$.

Ophthalmic ultrasound evaluation using $10-\mathrm{MHz}$ and $20-\mathrm{MHz}$ transducers (Ultrascan ${ }^{\circledR}$, Alcon) and A- and B-mode was performed with direct contact technique, after topical anesthetic instillation of $0.5 \%$ proxymetacaine hydrochloride (Anestalcon ${ }^{\circledR}$, Alcon, USA). Longitudinal, transverse, axial, and paraxial sections through the macula were studied by using both high and medium gain settings (70-80 dB) to detect vitreous abnormalities following by the attenuation of gain ( $65 \mathrm{~dB}$ ) to evaluate the macular area. We compared the resultant images obtained from the $10-\mathrm{MHz}$ and $20-\mathrm{MHz}$ ultrasound probes, regarding the resolution (or the definition of the structures images allowing them to be properly distinguished) and the sensibility (or the capacity to detect the same structure with a lower gain).

The same eyes submitted to US evaluation were also analyzed by SD-OCT (Spectralis ${ }^{\circledR}$, Heidelberg Engineering, Inc., Germany) after pupil dilation using 1\% tropicamide (Mydriacyl ${ }^{\circledR}$, Alcon, USA). Regarding the technical parameters of the SD-OCT, 40000 A-scans were acquired per second using an optical resolution of approximately $7 \mathrm{~mm}$ in depth (axial resolution) and $14 \mathrm{~mm}$ transversally (lateral optical resolution). For the A-scans the scan depth was $1.8 \mathrm{~mm} / 512$ pixels, providing a digital axial resolution of $3.5 \mu \mathrm{m} /$ pixel, per volume scan of $20 \times 15$ degrees. B-scans covered a transversal range of 15, 20 and $30^{\circ}$ field of view. Vertical and horizontal OCT scans were placed in the area of interest with reference to the vitreoretinal interface. In addition, 3D volumetric OCT scans were acquired for comprehensive analysis of the entire retina and, therefore, for 3D mapping of pathologic changes within the retinal layers.

Both OCT and US images were assessed by two independent observers who were unaware of the diagnosis (NA and VT). MH was classified by OCT evaluation in stages I to IV based on the Gass' classification ${ }^{(6)}$. Any evidence of epiretinal membrane (ERM) was noted as well as the presence or absence of posterior vitreous detachment (PVD).

\section{RESULTS}

The study included 22 patients with biomicroscopy evidence of $\mathrm{MH}$, six men (27.28\%), 16 women (72.72\%), mean age of 64.89 years (range 12 to 76 years) as in table 1 . The 12 year-old patient had a trau-
Table 1. Data of patients with macular hole of different stages classified according to Gass

\begin{tabular}{|c|c|c|c|c|c|}
\hline $\begin{array}{l}\text { Patient } \\
\text { № }\end{array}$ & Gender & $\begin{array}{c}\text { Age } \\
\text { (years) }\end{array}$ & Eye & $\begin{array}{c}\text { Macular } \\
\text { hole stage }\end{array}$ & Observation \\
\hline 1 & M & 76 & OD & IV & \\
\hline 2 & F & 67 & OS & III & \\
\hline 3 & $F$ & 68 & OS & III & \\
\hline 4 & F & 63 & OD & III & \\
\hline 5 & F & 64 & OD & III & \\
\hline 5 & F & 64 & OS & - & PPV \\
\hline 6 & $\mathrm{~F}$ & 55 & OD & IV & \\
\hline 7 & M & 68 & OD & III & \\
\hline 7 & M & 68 & OS & - & PPV \\
\hline 8 & $\mathrm{~F}$ & 63 & OD & & ERM \\
\hline 8 & $\mathrm{~F}$ & 63 & OS & IV & \\
\hline 9 & M & 66 & OD & $\|$ & \\
\hline 9 & M & 66 & OS & III & \\
\hline 10 & $\mathrm{~F}$ & 63 & OS & III & \\
\hline 11 & $F$ & 66 & OD & III & \\
\hline 12 & M & 71 & OD & III & \\
\hline 12 & M & 71 & OS & - & PPV \\
\hline 13 & $\mathrm{~F}$ & 65 & OD & III & \\
\hline 14 & $F$ & 73 & OS & III & \\
\hline 15 & $\mathrm{~F}$ & 69 & OD & - & ERM \\
\hline 16 & $\mathrm{~F}$ & 72 & OS & III & \\
\hline 16 & $\mathrm{~F}$ & 72 & OD & IV & \\
\hline 17 & M & 12 & OS & IV & \\
\hline 18 & $\mathrm{~F}$ & 65 & OD & - & ERM \\
\hline 18 & $\mathrm{~F}$ & 65 & OS & - & ERM \\
\hline 19 & $\mathrm{~F}$ & 61 & OD & I & \\
\hline 20 & $F$ & 68 & OD & I & \\
\hline 21 & M & 69 & OS & III & \\
\hline 22 & $\mathrm{~F}$ & 69 & OS & III & \\
\hline
\end{tabular}

$\mathrm{PPV}=$ pars plana vitrectomy; $\mathrm{ERM}=$ epiretinal membrane; $\mathrm{OD}=$ right eye; $\mathrm{OS}=$ left eye; $\mathrm{M}=$ male; $\mathrm{F}=$ female.

matic $\mathrm{MH}$. Seven patients (31.81\%) had impending or full-thickness $\mathrm{MH}$ in the fellow eye at presentation. Four eyes had previously been submitted to vitreoretinal surgery for $\mathrm{MH}$ repair.

All patients presented with symptoms that included decreased vision, distortion, central spots and/or some degree of metamorphopsia in one eye (15 patients) or both eyes (7 patients). Macular area fundus biomicroscopy identified 29 eyes with MH. SD-OCT identified MH in 25 of 29 eyes. Four eyes had, in fact, pseudoholes caused by ERM.

In MH stages I (2 eyes) and II (1 eyes), both 10 and 20-MHz US were not a useful tool to analyze macular thickening. In certain cases, suggestive findings of maculopathy such as macular irregularity and image consistent with prefoveal operculum and perifoveal PVD were highlighted (Figure 1). In these cases, OCT was superior to US since it clearly defined the outline of the hole (Table 2).

In MH stages III (14 cases) and IV (5 cases), both US probes identified the double hump irregularity and thickening of the ocular wall. Ultrasound could measure the macular thickness and identified other 


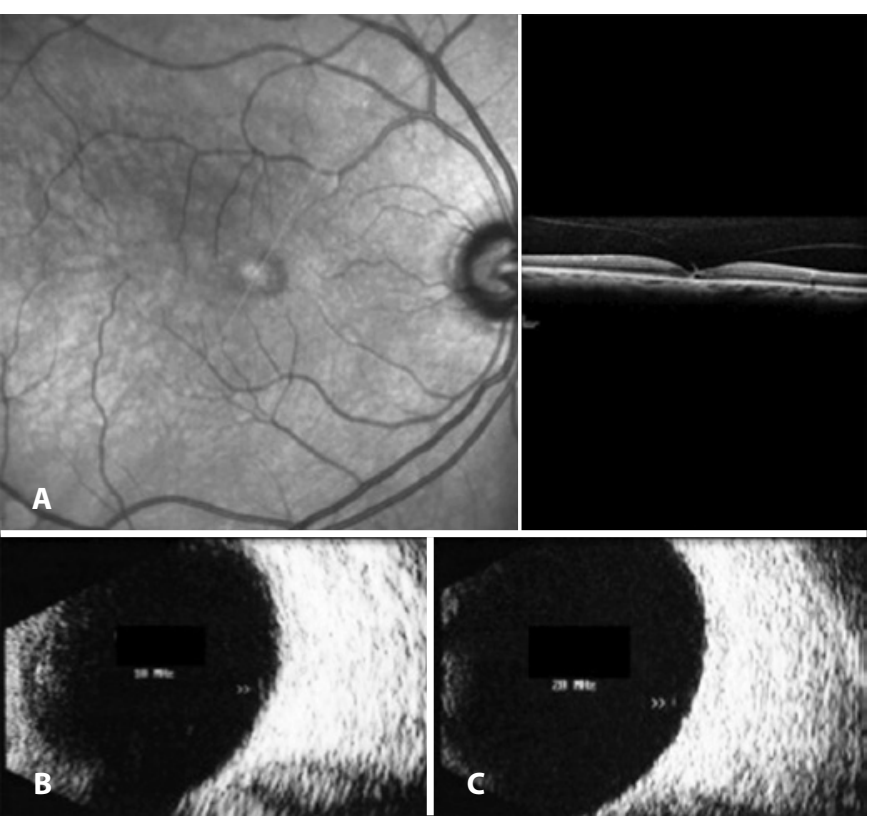

Figure 1. A) Optical coherence tomography (SD-OCT) of a stage I macular hole. B $(10-\mathrm{MHz})$ and C) (20-MHz), B-scan ultrasound shows the vitreoretinal interface with adhesion to the macular area.

Table 2. Ultrasound findings in relation to different stages of macular hole (Gass classification)

\begin{tabular}{ll}
\hline Stage & \multicolumn{1}{c}{ B-scan ultrasonography } \\
\hline $\begin{array}{l}\text { Stage I } \\
n=2\end{array}$ & Retinal surface irregularity \\
& Perifoveal PVD \\
& Vitreomacular adhesion \\
& Image suggestive of pseudo-operculum \\
& Retinal surface irregularity \\
$n=1$ & Vitreomacular adhesion \\
& Image suggestive of pseudo-operculum \\
& PVD attached at optic nerve \\
& Double hump irregularity \\
$n=14$ & Variable macular thickening \\
& Echodense operculum \\
& Partial PVD attached at optic disc \\
& \\
Stage IV & Double hump irregularity \\
& Macular thickening \\
& Echodense operculum \\
& Complete PVD with Weiss ring \\
& Macular irregularity \\
& Discrete depression in some cases \\
&
\end{tabular}

$\mathrm{PVD}=$ posterior vitreous detachment

suggestive ultrasonographic findings as operculum, vitreomacular traction (VMT) or partial perifoveal PVD: still attached to the papilla (stage III) (Figure 2) or completely detached from the posterior pole (stage IV) (Figure 3).

Ultrasound detected partial PVD with perifoveal vitreous detachment in 20 of the 29 eyes analyzed (68.96\%). In the remaining 9
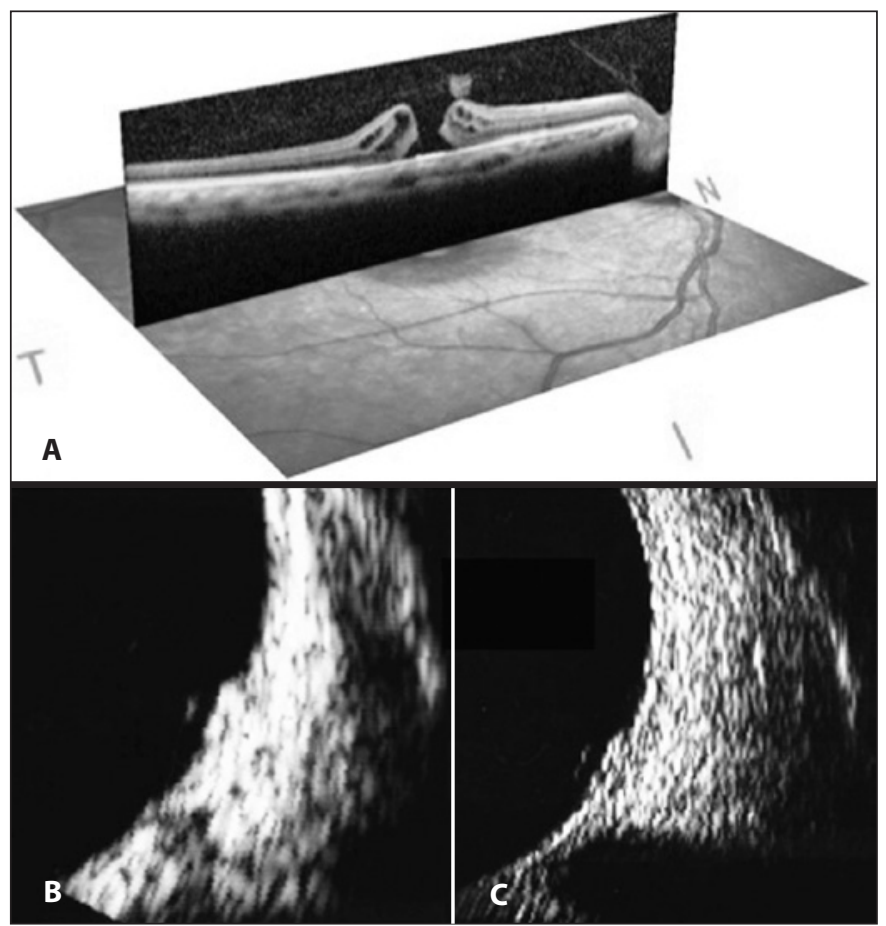

Figure 2. A) Optical coherence tomography (SD-OCT) of an operculated stage III macular hole. B) (10-MHz) and C) (20-MHz), B-scan ultrasound shows macular thickening, double hump irregularity and a shallow vitreous detachment with vitreous adherence at the fovea and the operculum overlying the macular hole. $20-\mathrm{MHz}$ B-scan ultrasound suggests the presence of macular hole with higher definition.

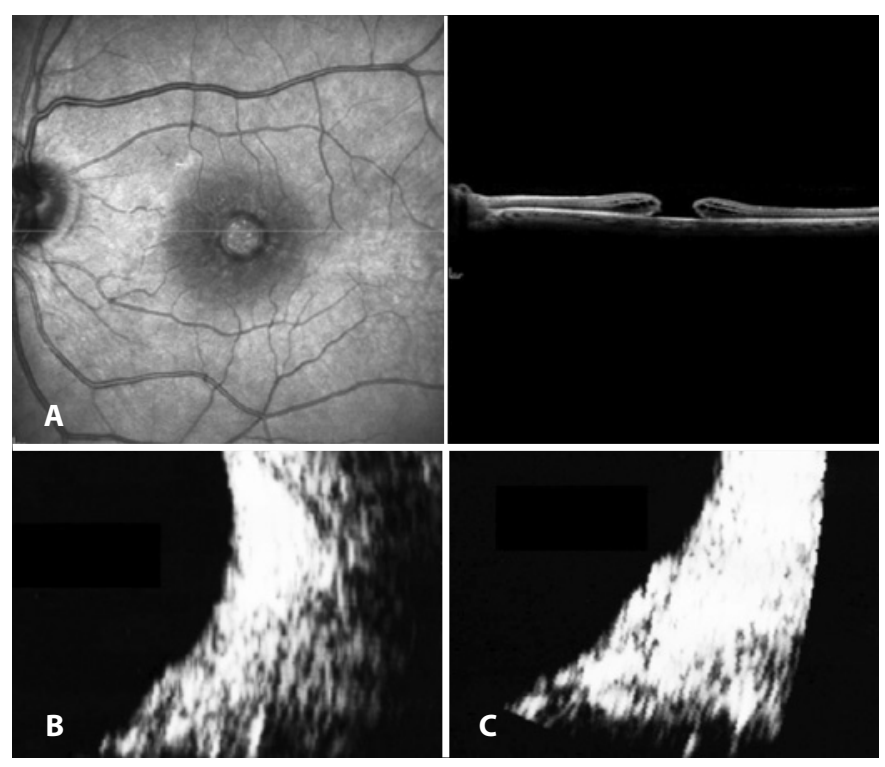

Figure 3. A) Optical coherence tomography (SD-OCT) of a stage IV macular hole. B) $(10-\mathrm{MHz})$ and $\mathrm{C})(20-\mathrm{MHz}), \mathrm{B}-\mathrm{scan}$ ultrasound shows macular thickening and double hump irregularity.

eyes, 5 had total PVD, 1 was unclear by either OCT and US, and 3 had previously been submitted to pars plana vitrectomy. However, the OCT performed in the same 29 eyes was able to identify the partial PVD in only 13 eyes.

In all cases, OCT provided the advantage of a more precise measurement of the MH dimensions. In cases of pseudoholes (4 cases), 
US identified irregularity of the macular contour as well as a discrete depression. OCT identified an operculum in 13 eyes, while US highlighted only 9 of them (69.23\%).

\section{DISCUSSION}

The advent of OCT provided unprecedented visualization of the vitreomacular interface, which has led to a better comprehension of MH formation ${ }^{(3)}$. This cross-sectional imaging technology has allowed investigators to study, in a non-invasive manner, the disease processes that were previously unrecognizable by biomicroscopy alone. Vitreomacular adhesion plays a larger role in retinal disease than was previously understood ${ }^{(7)}$. OCT is still the gold standard for the diagnosis of macular diseases, unless in cases of opaque media when images cannot be acquired, or when OCT devices are not available. In these conditions, the combined ultrasonographic study using 10 and $20-\mathrm{MHz}$ can provide a valid evaluation of the vitreoretinal interface ${ }^{(8)}$.

Macular hole can occur in either gender, at any age, with no racial predilection ${ }^{(9)}$. The incidence in women is higher, that may be attributed to the earlier onset of PVD due to premature vitreous liquefaction, probably associated with declining estrogen levels in the postmenopausal period ${ }^{(10)}$. This profile is also seen in ERM, another condition considered to be a complication of $\mathrm{PVD}^{(11)}$. In this study, evidence of $\mathrm{MH}$ was present in 16 women (72.72\% of the patients), in accordance with other studies ${ }^{(10,11)}$.

Nowadays, vitreofoveal traction is believed to be important in the pathogenesis of idiopathic $\mathrm{MH}$. Since Gass has described its early stages, the development of this pathology was attributed to tangential traction of the prefoveal vitreous cortex resulting in a foveal dehiscence that can progress from foveolar detachment to a mature full-thickness $\mathrm{MH}^{(5,6)}$. However, Gass' theory has been modified after the advent of new technologies, as SD-OCT and US.

Some susceptible patients have abnormal and strong vitreomacular adherence, causing persistent foveal traction with perifoveal detachment, which is universally associated with the earliest $\mathrm{MH}$ stages. The continuous anterior traction of the slightly detached vitreous cortex appears to be a major contributing factor to $\mathrm{MH}$ formation. Both types of traction: anteroposterior and tangential, might be combined in some cases. Tangential traction may also be the result of glial cell proliferation onto the perifoveal internal limiting membrane and may explain the persistence and enlargement of $\mathrm{MH}$, in some specific cases, even when the posterior hyaloid spontaneously detaches ${ }^{(3)}$. Hikichi et al. reported that complete PVD can prevent $\mathrm{MH}$ formation or further deterioration of visual acuity in most eyes with full-thickness $\mathrm{MH}^{(12)}$. Further, recent studies about pharmacovitreolysis (Ocriplasmin ${ }^{\circledR}$, ThromboGenics) demonstrate that the induction of both liquefaction and separation of the vitreous from the retinal interface can result in increased rates of PVD and $\mathrm{MH}$ resolution, avoiding surgical procedures. Resolution of VMT and $\mathrm{MH}$ resulted in visual improvement in most patients ${ }^{(13)}$. These findings also contribute to the theory of anteroposterior traction as an important role to $\mathrm{MH}$ formation. Mechanisms other than VMT may additionally contribute to the development of $\mathrm{MH}$, such as hydration of retinal edges after dehiscence formation, foveal degenerative changes ${ }^{(14-16)}$ and the diameter of the vitreous attachment in eyes with PVD correlated with induced changes in foveal anatomy ${ }^{(17)}$. In the current study, US detected partial PVD with perifoveal vitreous detachment in 20 of the 29 eyes analyzed (68.96\%). All patients with stages I and II had evidence of VMT, corroborating to the theory that the anteroposterior traction is generally associated with earlier MH stages.

The main value in understanding pathogenic theory is to identify possible therapeutic implications: a vitrectomy with the aim of resolving anteroposterior traction could be the main goal of a surgical procedure when the vitreous face is not totally separated from the edge of the $\mathrm{MH}$. Otherwise, when no anteroposterior traction is shown by OCT or US, the surgeon would attempt to remove epireti- nal tissue and internal limiting membrane to release the tangential traction ${ }^{(3)}$. Moreover, the differentiation between VMT and PVD, by a noninvasive technique, is inevitable and decisive for further surgical or pharmacological treatment and the B-scan US served as the most reliable noninvasive technique, between biomicroscopic and OCT, to assess the status of posterior vitreous cortex prior to vitrectomy ${ }^{(18,19)}$ (Figure 4).

In the current study, $\mathrm{MH}$ was detectable by both 10 and $20-\mathrm{MHz}$ ultrasound transducers, with different findings, concerning each specific stage (Table 2). The 10-MHz ultrasonography was useful for an overall assessment of the vitreous body, its mobility, and the relationship between the posterior hyaloid membrane and the retina, as well as the position of the posterior vitreous face. The $20-\mathrm{MHz}$ examination was able to provide valuable information on the analysis of the vitreomacular interface and macular contour. 10-MHz systems may be advantageous compared with $20-\mathrm{MHz}$ systems where deeper penetration is important (choroid analysis, i.e.). It has superior sensitivity than the $20-\mathrm{MHz}$ probe and can be used to examine low intensity scatterers, such as weakly echoing vitreous structures that cannot be easily seen using higher frequency probe ${ }^{(20)}$. Meaning that, to give similar display strength of structures seen with the $10-\mathrm{MHz}$ probe, the $20-\mathrm{MHz}$ required a higher gain setting than the $10-\mathrm{MHz}$ probe ${ }^{(20)}$. Otherwise, the comparatively superior resolution of $20-\mathrm{MHz}$ systems relative to $10-\mathrm{MHz}$ can provide an advantage in axial and lateral resolution for imaging of the posterior segment that can increase diagnostic capability for subtle retinal pathologies. The $10-\mathrm{MHz}$ probe does not provide as good definition as the $20 \mathrm{MHz}$ probe, and can suffer from saturation of the image ${ }^{(20)}$. These findings are in accordance with the results obtained by Hewick et al ${ }^{(20)}$. Nevertheless, it is important to consider that, for the complete assessment and analysis of the vitreoretinal interface and status of the posterior vitreous cortex, both US transducers of 10 and 20-MHz are complementary and provide additional information.

The ultrasonographic exam for $\mathrm{MH}$ stages I and II demanded a very rigorous examination protocol. US images were suggestive when associated with pseudo-operculum or shallow localized separation of posterior hyaloid from the perifoveal retina, when it could be detected a thin membrane with fine anteroposterior vitreous fibers and vitreomacular adhesion, associated with a slightly irregular retinal surface.
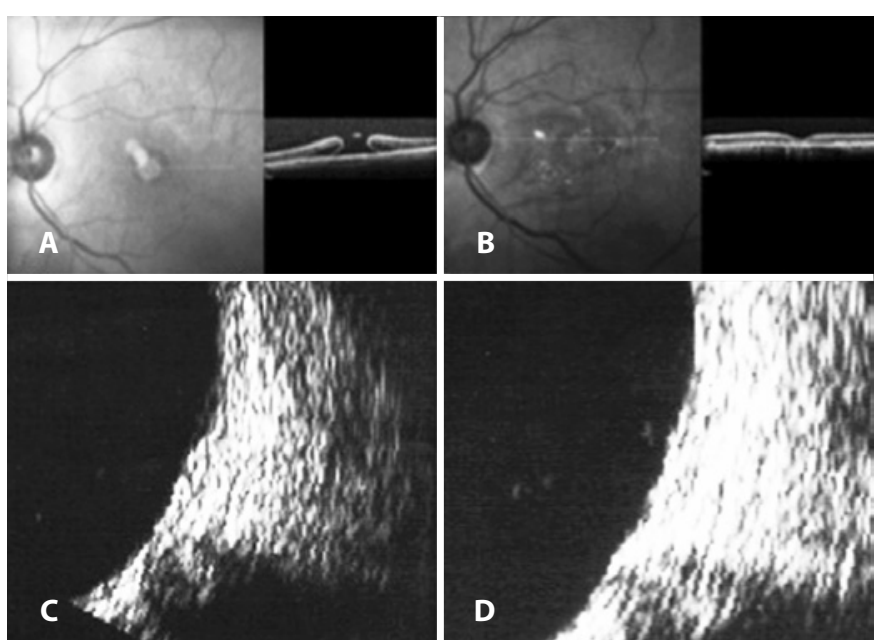

Figure 4. A) Optical coherence tomography (SD-OCT) of an operculated stage III macular hole. B) SD-OCT of the same eye, after pars plana vitrectomy with peeling of the internal limiting membrane. C) 20-MHz B-scan ultrasound shows macular thickening, double hump irregularity and a perifoveal vitreous detachment with vitreous adherence at the fovea. D) 20-MHz B-scan ultrasound of the macular area after vitrectomy surgery, with absence of the double hump and macular thickening. 
Considering $\mathrm{MH}$ stage III, the ultrasonographic findings were variable macular thickening, double hump irregularity, with or without images consistent with prefoveal pseudo-operculum (small echodense opacity suspended anterior to the foveolar area) and attached to a thinner echodense linear opacity that appeared to connect to the prepapillary glial tissue nasally, suggesting the diagnosis of a partial PVD.

For MH stage IV, a mobile echodense linear opacity ring (suggestive of the Weiss ring) was detectable anterior to the retina, characterizing a total PVD. This was more prominent during kinetic examination; macular thickening, with double hump irregularity was also detected. Ultrasound was more sensitive than OCT in detecting the relationship between the PHM and the $\mathrm{MH}$, therefore the US may be a useful adjunct in the differentiation between $\mathrm{MH}$ stages III and IV. In cases of ERM, US identified irregularities of the macular area contour. A discrete depression could be detected in some cases, usually associated with complete PVD. All these findings related to the vitreous status and macular contour, in cases of different stages of $\mathrm{MH}$, were in accordance with other studies ${ }^{(4,20,21)}$.

OCT, however, enjoys significantly better resolution and sensitivity than US and remains a better tool for the morphological study of macular diseases, unless in cases of opaque media or to accurately demonstrate the position of the posterior vitreous face. Moreover, OCT is limited to the central fundus because images are acquired through the pupil, so the vitreous body cannot be evaluated completely. There are limitations on OCT that may lead to an underestimation of the true incidence of VMT, as missing sites of vitreoretinal adhesion, inadequate reflectivity of vitreous, vitreous elevation outside the focal range or peripheral PVD, media opacity or poor patient cooperation ${ }^{(22)}$.

The clinical role of US must be placed in the context of what is and is not achievable with OCT. Under certain circumstances, as in the presence of optical media opacity, when the stage of the complete vitreous body is imperative, as in cases of $\mathrm{MH}$, or even when OCT devices are not available, the ultrasonographic study can be useful and offers information complementary to that obtained by $O C T$, mainly related to the vitreous body ${ }^{(1)}$. Furthermore, it is expected that the evolution of ultrasound will move in several areas: scanning instrumentation will become cheaper and more widely available and transducer technology will evolve to allow greater depth of field and spatial orientation maintaing or even gaining resolution ${ }^{(23)}$.

In conclusion, US of the macular area, when used with a proper technique, may be a complementary tool to OCT and can improve the understanding of the relationship between the posterior vitreous cortex and the retina. OCT remains better for the fine morphological study of macular details in eyes with $\mathrm{MH}$. In cases of opaque media or when OCT cannot be performed, the combined US study not only affords a valid evaluation of the macular area, but also gives useful information related to the vitreomacular interface, thus improving therapeutic approach.

\section{REFERENCES}

1. Coleman DJ, Silverman RH, Chabi A, Rondeau MJ, Shung KK, Cannata J, et al. High-resolution ultrasonic imaging of the posterior segment. Ophthalmology. 2004; 111(7):1344-51.

2. Primiano Junior HP, Nakashima AF, Maia OO Jr, Bonanomi MT, Nakashima Y. [A study of idiopathic vitreomacular traction syndrome with optical coherence tomography images: cases report]. Arq Bras Oftalmol. 2007;70(1):143-7. Portuguese.

3. Glacet-Bernard A, Zourdani A, Perrenoud F, Coscas G, Soubrane G. Stage 3 macular hole: role of optical coherence tomography and of B-scan ultrasonography. Am J Ophthalmol. 2005;139(5):814-9.

4. Van Newkirk MR, Johnson MW, Hughes JR, Meyer KA, Byrne SF. B-scan ultrasonographic findings in the stages of idiopathic macular hole. Trans Am Ophthalmol Soc. 2000;98:163-9; discussion 169-71.

5. Gass JD. Idiopathic senile macular hole. Its early stages and pathogenesis. Arch Ophthalmol. 1988;106(5):629-39.

6. Gass JD. Reappraisal of biomicroscopic classification of stages of development of a macular hole. Am J Ophthalmol. 1995;119(6):752-9.

7. Mirza RG, Johnson MW, Jampol LM. Optical coherence tomography use in evaluation of the vitreoretinal interface: a review. Surv Ophthalmol. 2007;52(4):397-421.

8. Goncalves AC, Moura FC, Moura JP, Bloise W, Monteiro ML. [A comparative study between the results of antro-ethmoidal orbital decompression isolated and associated with orbital fat removal]. Arq Bras Oftalmol. 2005;68(4):445-9. Portuguese.

9. McDonald HR, Johnson RN, Schatz H. Surgical results in the vitreomacular traction syndrome. Ophthalmology. 1994:101(8):1397-402; discussion 1403.

10. Yonemoto J, Ideta H, Sasaki K, Tanaka S, Hirose A, Oka C. The age of onset of posterior vitreous detachment. Graefes Arch Clin Exp Ophthalmol. 1994;232(2):67-70.

11. Johnson MW, Van Newkirk MR, Meyer KA. Perifoveal vitreous detachment is the primary pathogenic event in idiopathic macular hole formation. Arch Ophthalmol. 2001;119(2):215-22.

12. Hikichi T, Akiba J, Trempe CL. Effect of the vitreous on the prognosis of full-thickness idiopathic macular hole. Am J Ophthalmol. 1993;116(3):273-8.

13. Stalmans P, Delaey C, de Smet MD, van Dijkman E, Pakola S. Intravitreal injection of microplasmin for treatment of vitreomacular adhesion: results of a prospective, randomized, sham-controlled phase II trial (the MIVI-IIT trial). Retina. 2010;30(7):1122-7.

14. Gaudric A, Haouchine B, Massin P, Paques M, Blain P, Erginay A. Macular hole formation: new data provided by optical coherence tomography. Arch Ophthalmol. 1999; 117(6):744-51.

15. Ito $Y$, Terasaki $H$, Suzuki T, Kojima T, Mori M, Ishikawa $K$, et al. Mapping posterior vitreous detachment by optical coherence tomography in eyes with idiopathic macular hole. Am J Ophthalmol. 2003;135(3):351-5.

16. Haouchine B, Massin P, Gaudric A. Foveal pseudocyst as the first step in macular hole formation: a prospective study by optical coherence tomography. Ophthalmology. 2001;108(1):15-22.

17. Spaide RF, Wong D, Fisher Y, Goldbaum M. Correlation of vitreous attachment and foveal deformation in early macular hole states. Am J Ophthalmol. 2002;133(2):226-9.

18. Kicova N, Bertelmann T, Irle S, Sekundo W, Mennel S. Evaluation of a posterior vitreous detachment: a comparison of biomicroscopy, B-scan ultrasonography and optical coherence tomography to surgical findings with chromodissection. Acta Ophthalmol. 2012; 90(4): e264-8

19. Carrero JL. Incomplete posterior vitreous detachment: prevalence and clinical relevance. Am J Ophthalmol. 2012;153(3):497-503.

20. Hewick SA, Fairhead AC, Culy JC, Atta HR. A comparison of $10 \mathrm{MHz}$ and $20 \mathrm{MHz}$ ultrasound probes in imaging the eye and orbit. Br J Ophthalmol. 2004:88(4):551-5.

21. Siahmed K, Berges O, Brasseur G. [Macular hole evaluation with $10-\mathrm{MHz}$ and $20-\mathrm{MHz}$ ultrasonography and optical coherence tomography]. J Fr Ophtalmol. 2005;28(7): 733-6. French.

22. Gallemore RP, Jumper JM, McCuen BW 2nd, Jaffe GJ, Postel EA, Toth CA. Diagnosis of vitreoretinal adhesions in macular disease with optical coherence tomography. Retina. 2000;20(2):115-20.

23. Coleman DJ, Silverman RH, Rondeau MJ, Lloyd HO, Daly S. Explaining the current role of high frequency ultrasound in ophthalmic diagnosis (Ophthalmic Ultrasound). Expert Rev Ophthalmol. 2006;1(1):63-76. 